\title{
On the Training Model of Professional Translators' Ability in Translation Major of Colleges and Universities
}

\author{
Jiang Yan and Gui Renna \\ (Nanchang Institute of Technology, Nanchang, 330099)
}

\begin{abstract}
Keywords: College students; Colleges and universities; Professional translators; Training mode
\end{abstract}
\begin{abstract}
Under the background of translation industrialization and professionalization transformation, college translation majors must not only train students in bilingual transitions and technology/tools abilities, but also focus on cultivating students to select careers, transfer jobs and to adapt to occupational changes, as well as the abilities of cooperation, organization and coordination in the translation of industrial clusters and even related professional groups. Translation ability, method ability and social ability constitute the professional abilities of the translator as a whole, and the study of translator ability to work must shift the study of "translation ability" to the study of "professional ability".
\end{abstract}

\section{Introduction}

With the expansion of the scale of enrollment in translation major, many problems have become increasingly prominent, especially in terms of cultivating quality issues. That is to say, the translation ability of translation masters is far from the actual needs of the society, leading to a sharp shortage of translators. Therefore, how to train excellent translators combining the translation market with translation teaching is an urgent problem to be solved. This paper sorts out the research literature on translation abilities and analyzes the differences in translation ability between students of translation major and professional translators, and the differences in the translation ability of professional translators and students of translation major from different backgrounds, which are bilingualism, extra language ability, translation expertise, tool ability and strategic ability. Training complex translators has become a key point. Promoting the translation abilities of students of translation major helps to develop "high-level, applied and professional" translators who meet the needs of translation industry.

\section{Abilities Which Professional Translators should have}

Many people think that professional translators only need to be proficient in a foreign language. There are many misconceptions about professional translators. Mastering a foreign language is just the basis for becoming a qualified translator. Professional translators also need to have a certain level of translation skills and qualities. Taking English as an example, Chai Mingying proposed that almost every college student has studied English, but not every college student can become a good translator.

In addition to being proficient in a foreign language, it also requires the following basic qualities:

1.Bilingual foundation is good: Objectively and faithfully translate the content of the original or source language.Chai Ming said that people who have not undergone professional translation training often add their own imagination to the description of the translated content, including personal ideas and meanings. However, qualified translators must be faithful to the speaker's intentions in order to give the listener correct judgment information.

2.Knowledge is broad: Translator is actually a "syncretism" who needs to be involved in all fields, including politics, economy and law. Chai Ming introduced that in the process of translation, many fields will be involved. If a translator does not know anything about this, it will be very difficult to translate the technical jargon in specialized fields, which will cause unnecessary troubles for translation work.

3.Logical thinking skills are strong: This is also known as the ability to analyze. Chai Ming 
believed that each person's speech has its own logic, which requires the translator to master the logic of the language during translation, and after reasonable combination of information, the information should be passed to listeners through the target language.

4.Response is quick: A qualified translator also needs to have quick response, clear eloquence and other qualities. If even the most basic qualities of a translator cannot be achieved, then he will not become a potential qualified translator.

\section{Status quo of professional English translation teaching in colleges and universities}

\section{Limitations of teaching materials and tests of college English}

At present, college English teaching materials used in many colleges and universities do not have the basic theory of translation or commonly used translation methods or skills. Even if someteaching materials have several sentences translation after the class, they areonly to consolidate or emphasize the words, phrases or grammar in the class, which cannot be considered as the training of translation, but the comprehensive practice on words, phrases, grammarand sentence.

2.Insufficient translation theoretical knowledge

Theory is the guide of practice. Translation requires a good translation theory as the basic guarantee. Only with a deep theoretical foundation, can translation be vivid. However, colleges and universities neglect the theoretical knowledge in teaching translation, which in turn cause teachers seldom teach translation theory or skill but only literal translation. Even if students have a large vocabulary and a lot of grammar knowledge, the translation will be very blunt without emotion.

3.Backward teaching mode

There are relatively few class hours in colleges and universities, and the translation basically comes from the classroom. In the classroom, it is basically teacher-centered. Teachers arrange several translation tasks that are out of the actual context, and then make corrections and reviews. This has little effect on students' translation ability. Students are most likely to remember a few words or phrases, and few gains are made. Students will find translation is useless, thus misunderstandthe translation teaching of college English and hinder the normal operation of English translation teaching.

\section{Teaching strategies for professional English translation of colleges and universities}

Cultivating the English translation ability of college students is very important for future professional English translation. In view of the current status of college English translation teaching in colleges and universities, combining practical teaching experience, this paper puts forward concrete solutions and measures based on the analysis of problems, including the following aspects:

1.Increase translation classhours settings

Many students have good English listening, speaking, reading and writing skills and can pass the exam smoothly. However, when translating professional business articles, they often face great difficulties. At the same time, various errors occur in the process of translation. Especially in the process of interpreting, the errors are more serious. In view of this, colleges and universities should pay attention to increase the class hours of translation. In the curriculum, try to integrate with the society and cultivate translators who can adapt to the society.

2.Select rational teaching materials

When compiling college English textbooks, relevant regulations should be followed to keep consistent with the syllabus, and fundamentally improve students' English translation skills.Specifically speaking, there are several requirements for the rational selection of teaching materials.First, to effectively integrate English-Chinese translation with Chinese-English translation and to expand students' knowledge and to promote the integration of translation knowledge. Second, emphasize the integration of theoretical knowledge and practical knowledge. Third, in the content of teaching materials, the differences between the East and West cultures should be involved so that students can learn more about Western cultural knowledge and strengthen foreign cultural awareness. 


\section{Innovate English teaching model}

According to the above discussion, it can be seen that the traditional model used by teachers in English translation teaching has a lot of drawbacks, and it is difficult to improve students' ability in English translation.Therefore, teachers must break the traditional teaching mode in time and constantly innovate teaching methods and concepts. For example, heuristic teaching methods can be used. Specifically, on the basis of the task of independently completing the translation, students should adopt the method of self-evaluation, group comment and standard text to compare the best translations. At the same time, in this process, students can also find their own problems and make timely corrections.

\section{Conclusion}

This paper first analyzes the ability which the current professional English translators should have, and the abilitywhich college students of translation major are lack of, and then combining with the current status of college English translation teaching and the actual teaching experience, this paper proposes improvements and measures. For example, to increase the setting of translation class hours; to rationally select teaching materials; to innovate the model of English teaching and to improve the professional qualities of teachers. The author hopes it can serve as a reference. All in all, it is necessary to adopt a multi-pronged approach, to attach importance to the cultural differences between the East and the West and to cultivate students'interest in English knowledge, in order to improve students' English translation ability.

\section{Acknowledgement}

Project funding: The subject of educational teaching reform in Nanchang Institute of Technology(No. 2017JG012)

\section{References}

[1] Tao Y. Towards a constructive model in training professional translators : a case study of MTI education program in China[J]. Babel, 2012, 58(3):289-308.

[2] Zhao L X. A Study of the Optimization of College Translation Teaching Orientated by Professional Translators' Competence[J]. Journal of Central South University of Forestry \& Technology, 2014.

[3] Chodkiewicz M. The EMT framework of reference for competences applied to translation: perceptions by professional and student translators[J]. 2012, 17:37-54.

[4] Kučiš V. Online translation tools as didactical material in the training of professional translators[J]. Didactica Slovenica, 2011.

[5] Liu J W, Sun X L. Study on the Setting of Courses for MTI Based on the Cultivation of Translators' Abilities[J]. Journal of Qiqihar Junior Teachers College, 2012.

[6] Almeida e P J M C. Translation for Publishing: a journey into the world of translators and publishers in Portugal (1974-2009)[J]. New Voices in Translation Studies, 2013.

[7] Zhang Q. A Study on the Influence of Translators' Self-Revision on Translation Quality_-Taking the Third-Year English Majors' C-E Translation as an Example[J]. Journal of Xian International Studies University, 2014.

[8] Hubscherdavidson S. Trait Emotional intelligence and translation: A study of professional translators[J]. Target, 2016, 28(1):págs. 132-157.

[9] Qiu B. A Study of the Importance and Operation Modes of Translator's Subjectivity in Terminology Translation-From the Perspective of Game Theory[J]. Foreign Language Education, 2015.

[10] Jia Y. Ability of Translator and Translation Teaching of MTI_-Inspirations of the Translation Training System of University of Mainz for the MTI in China[J]. Journal of Xian International Studies University, 2015. 
[11] Gallegohernández D. The use of corpora as translation resources: a study based on a survey of Spanish professional translators[J]. Perspectives, 2015, 23(3):375-391.

[12] Syczopoń J, Gałuskina K. Machine Translation in the Hands of Trainee Translators - an Empirical Study[J]. Studies in Logic Grammar \& Rhetoric, 2017, 49(1):195-212. 